\title{
Article \\ Effect of DA-9701 on the Gastrointestinal Motility in the Streptozotocin-Induced Diabetic Mice
}

\author{
Changyoon Ha ${ }^{1,2,3} \mathbb{D}_{\text {, Heejin Kim }}{ }^{1,3,4}$, Rari Cha ${ }^{1,3,4}$, Jaemin Lee ${ }^{1,3,4}$, Sangsoo Lee ${ }^{1,3,4}$, Jung-Hwa Ryu ${ }^{5}$, \\ Hyunjin Kim ${ }^{1,3,4, *}$ and Ok-Jae Lee ${ }^{1,2,3, * \mathbb{D}}$
}

1 Department of Internal Medicine, Gyeongsang National University College of Medicine, Jinju 52727, Korea; cyha@gnu.ac.kr (C.H.); heejin1231@hanmail.net (H.K.); rari83@naver.com (R.C.); 01179jm@naver.com (J.L.); 3939lee@naver.com (S.L.)

2 Division of Gastroenterology, Gyeongsang National University Hospital, Jinju 52727, Korea

3 Institute of Health Sciences, Gyeongsang National University, Jinju 52727, Korea

4 Division of Gastroenterology, Gyeongsang National University Changwon Hospital, Changwon 51472, Korea

5 Department of Internal Medicine, Ewha Womans University College of Medicine, Seoul 07804, Korea; singrum@gmail.com

* Correspondence: imdrkim@naver.com (H.K.); ojlee@gnu.ac.kr (O.-J.L.)

check for updates

Citation: Ha, C.; Kim, H.; Cha, R.; Lee, J.; Lee, S.; Ryu, J.-H.; Kim, H.; Lee, O.-J. Effect of DA-9701 on the Gastrointestinal Motility in the Streptozotocin-Induced Diabetic Mice. J. Clin. Med. 2021, 10, 5282. https:// doi.org/10.3390/jcm10225282

Academic Editor: Marilena Durazzo

Received: 29 September 2021

Accepted: 8 November 2021

Published: 13 November 2021

Publisher's Note: MDPI stays neutral with regard to jurisdictional claims in published maps and institutional affiliations.

Copyright: (c) 2021 by the authors. Licensee MDPI, Basel, Switzerland. This article is an open access article distributed under the terms and conditions of the Creative Commons Attribution (CC BY) license (https:// creativecommons.org/licenses/by/ $4.0 /)$.

\begin{abstract}
Background: Compared to the general population, diabetic patients experience more frequent episodes of gastrointestinal (GI) motility dysfunction, owing to the disruption of functional innervations. DA-9701 is a new prokinetic agent formulated from the extracts of Pharbitidis semen and Corydalis tuber. Aim: To investigate the effect of DA-9701 on GI motility in an animal model of streptozotocin (STZ)-induced diabetes. Methods: Diabetes was induced in mice by intraperitoneal injection of STZ ( $40 \mathrm{mg} / \mathrm{kg}$ of body weight in $0.1 \mathrm{M}$ citrate buffer) for 3 days. Diabetic mice were divided into four groups and administered DA-9701 in different doses $(1,3$, and $10 \mathrm{mg} / \mathrm{kg})$ or placebo for 2 weeks. Intestinal transit was assessed using charcoal meal movement. GI isometric contraction was measured by applying an isometric force transducer on a circular muscle strip of the antrum, ileum, and proximal colon of sacrificed mice. Gastric emptying rate was evaluated by measuring the dye percentage remaining in the stomach relative to the total dye amount recovered in a standardization group of mice. Results: Body weight and antral and small intestinal motility were less in diabetic mice than in control mice, and colonic motility was similar in both. DA-9701 showed a dose-dependent increase in the amplitude of spontaneous phasic contractions in the antrum, ileum, and colon in diabetic mice without influencing body weight or blood glucose levels. The degree of improvement was comparable between diabetic and control mice. Intestinal transit was significantly more delayed in diabetic mice than in controls ( $43 \pm 7 \%$ vs. $67 \pm 8 \%, p<0.05$ ); however, DA-9701 restored the delayed intestinal transit more effectively compared to placebo ( $75 \%$ vs. $50 \%$ ). The gastric emptying rate was significantly more delayed in diabetic mice than in controls $(43 \pm 10 \%$ vs. $62 \pm 12 \%, p<0.05)$, and was improved by DA-9701 in a dose-dependent manner $(50 \%, 55 \%$, and $60 \%$ in mice treated with 1,3 , and $10 \mathrm{mg} / \mathrm{kg}$ of DA-9701, respectively, vs. $43 \%$ in placebo-treated and $60 \%$ in control mice). Conclusions: DA-9701 improved GI contractility without affecting blood sugar and body weight in diabetic mice. DA-9701 could improve the decreased GI motility and clinical symptoms in progressive diabetic patients.
\end{abstract}

Keywords: DA-9701; diabetic mouse model; functional dyspepsia; diabetic gastroparesis; STZ; gastrointestinal motility

\section{Introduction}

Functional gastrointestinal (GI) disorders occur more frequently in patients with diabetes than in the general population. Longstanding diabetes induces GI motility dysfunction via the disruption of nerve functions regulating the motility of the gut, which causes incomplete emptying of the different sections of the gastrointestinal tract. This 
process finally leads to gastroenteropathy, a composite disorder of the esophagus, stomach, small intestine, and colon [1]. Thus, diabetic patients experience delayed gastric emptying (GE) and various GI symptoms, such as nausea, vomiting, early satiety, bloating, postprandial discomfort, anorexia, weight loss, and abdominal pain. Recently, more concise pathophysiologic mechanisms of diabetic gastroparesis have been elucidated; these include extrinsic denervation of the stomach, causing delayed gastric emptying, and loss of nitric oxide synthase (NOS) in the enteric nerve, causing impaired inhibitory input, which induces decreased gastric accommodation and decreased gastric emptying, pylorospasm, and altered function of immune cells, such as type 2 macrophages, which can trigger damage to the interstitial cells of Cajal (ICC) and smooth muscle atrophy [2,3].

DA-9701 is a new prokinetic agent formulated from the extracts of Pharbitidis semen and Corydalis tuber [4]. This medicine, which is known to function as a $5-\mathrm{HT}_{1 \mathrm{~A}}$ agonist, 5- $\mathrm{HT}_{4}$ agonist, and 5- $\mathrm{HT}_{3}$ partial antagonist, was developed for the treatment of functional dyspepsia [4-6]. Pharbitidis semen is known to have natural ingredients that control edema, fullness, fecal and urinary retention, phlegm, fluid retention, and abdominal pain due to parasitic infestations. Corydalis tuber is known to be effective in adjusting mild depression, severe nerve damage, tremors, and intestinal spasm [7].

In this study, we investigated the effect of DA-9701 on gastrointestinal motility, the intestinal transit, and gastric emptying rate in a streptozotocin (STZ)-induced diabetic mouse model.

\section{Materials and Methods}

\subsection{Streptozotocin (STZ)-Induced Diabetic Mice Model}

All animal care and experimental procedures were approved by the Ethics of Animal Experiments Committee of Kyungpook National University. Six-week-old male Institute of Cancer Research (ICR) mice weighing 25-30 g were used as experimental animals. They were housed at $24{ }^{\circ} \mathrm{C}$, were allowed free access to water and feed, and lighting was repeated in a darkness and lighting cycle every $12 \mathrm{~h}$. After acclimatization for 1 week, the mice were randomly divided into two groups: the STZ-induced diabetic group and the normal control group.

STZ was dissolved in $0.1 \mathrm{mM}$ citric acid buffer solution (STZ $40 \mathrm{mg} / \mathrm{kg}, \mathrm{pH} 4.0$ ) every day and injected via the intraperitoneal (IP) route for 3 consecutive days. In the normal control group, the same volume of citric acid buffer was injected intraperitoneally (Figure 1). Body weights were measured weekly during the experimental period. Two weeks after the first day of STZ injection, blood was collected from the tail vein and blood glucose levels were measured in each mouse. Individuals with a level of $\geq 300 \mathrm{mg} / \mathrm{dL}$ were considered to have diabetes. Blood glucose levels were measured at random times without overnight fasting using a GlucoDr ${ }^{\mathrm{TM}}$ Plus (Allmedicus, Anyang, Gyeonggi-do, Republic of Korea) test strip and a measuring instrument.

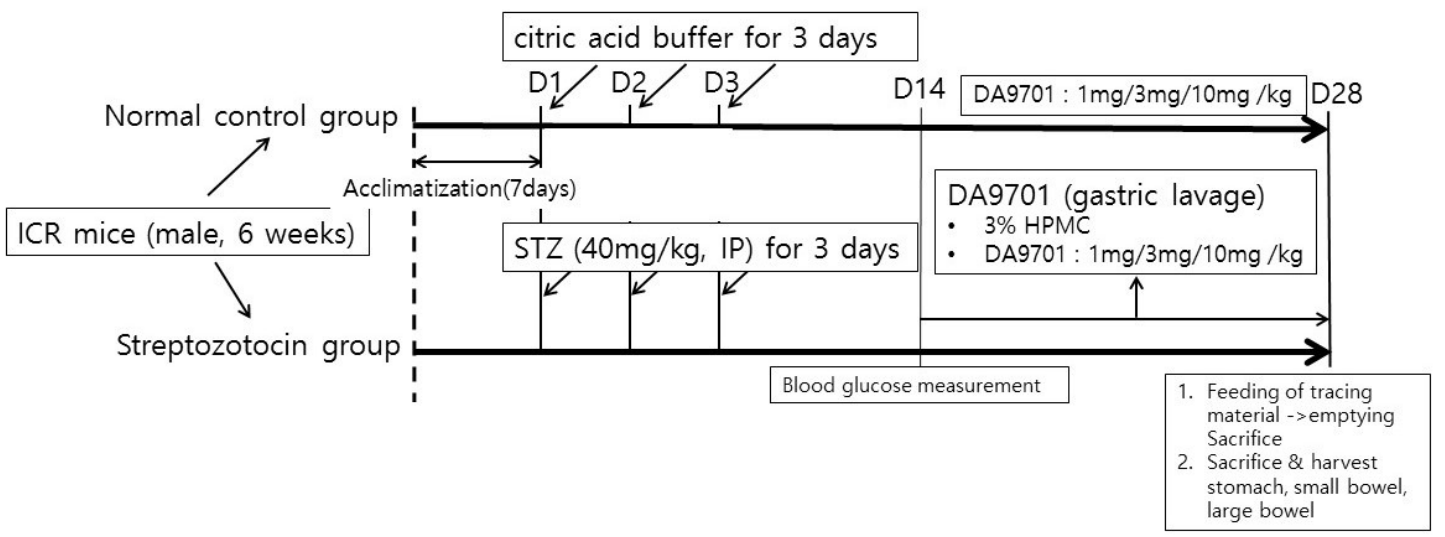

Figure 1. Schematic diagram of the experimental protocol. 
After the acclimatization phase of 7 days, streptozotocin was injected via intraperitoneal at a dose of $40 \mathrm{mg} / \mathrm{kg}$ for 3 days. The same volume of citric acid buffer was injected into normal control mice. Blood glucose level was measured after 14 days. Normal control and streptozotocin-induced mice were treated with DA-9701 in different doses $(1,3$, and $10 \mathrm{mg} / \mathrm{kg}$ ) for 14 days. On day 28 , all mice were sacrificed, and gastrointestinal motility was assessed.

\subsection{DA-9701 Treatment in Experimental Mice}

The STZ-induced diabetic mice were divided into four groups, each with 10 mice: STZ-induced diabetic mice treated with different doses of DA-9701 at 1, 3, and $10 \mathrm{mg} / \mathrm{kg}$, and STZ-induced diabetic mice with the placebo treatment. DA-9701 was suspended and administered orally at different doses of 1,3 , and $10 \mathrm{mg} / \mathrm{kg}$ for 2 weeks, and the placebo group was orally administered $3 \%$ hydroxypropyl methylcellulose (HPMC) for 2 weeks (Figure 1). To show the maximum changes in GI muscular contractility according to the DA-9701 dose escalation, the normal control or STZ-induced diabetic mice were also treated at higher doses $(>10 \mathrm{mg} / \mathrm{kg} ; 30,100$, and $300 \mathrm{mg} / \mathrm{kg})$. In this experiment, the mice were exposed to 1, 3, 10, 30, 100, and $300 \mathrm{mg} / \mathrm{kg}$ of DA-9701.

\subsection{Assessment of GI Motility Using Isometric Contraction Measurement}

All studies were performed on normal or STZ mice after 2 weeks of treatment with DA-9701 or placebo. DA-9701 was given to the mice in different doses of 1, 3, 10, 30, 100, and $300 \mathrm{mg} / \mathrm{kg}$. After $16 \mathrm{~h}$ of fasting, the mice were sacrificed. GI motility was evaluated by measuring isometric contractions in each segment of the bowel using circular muscle strips from the antrum, ileum, and proximal colon. From the sacrificed mice, $1-1.5 \mathrm{~cm}$ circular muscle strips of the antrum, ileum, and proximal colon were isolated and flushed with Krebs solution. The muscle strips were immediately placed in a $10 \mathrm{~mL}$ organ bath containing oxygenated $\left(95 \% \mathrm{O}_{2}+5 \% \mathrm{CO}_{2}\right) \mathrm{Krebs}$ solution at $37^{\circ} \mathrm{C}$. The distal end of the muscle segment was tied to a fixed mount and the tied proximal end was fixed to an isometric force-displacement transducer (FT-03, Grass-telefactor, Providence, RI, USA). Tension was monitored using an isometric force transducer and an index of the longitudinal muscle response was recorded. The signal was analyzed using a digital recording system. The signals from the transducers were processed using Powerlab 4/30 and Chart 7.2 (AD Instruments, Bella Vista, Australia).

The composition of Krebs solution was $10.1 \mathrm{mM}$ glucose, $115.5 \mathrm{mM} \mathrm{NaCl}, 21.9 \mathrm{mM}$ $\mathrm{NaHCO}_{3}, 4.61 \mathrm{mM} \mathrm{KCl}, 1.14 \mathrm{mM} \mathrm{NaH}_{2} \mathrm{PO}_{4}, 2.5 \mathrm{mM} \mathrm{CaCl}_{2}$, and $1.16 \mathrm{mM} \mathrm{MgSO}_{4}$.

\subsection{Measurement of Intestinal Transit}

All experiments were performed after 2 weeks of treatment with DA-9701 or 3\% HPMC (placebo). After $16 \mathrm{~h}$ of fasting, the mice were administered a single dose of liquid charcoal meal ( $10 \% w / v$ charcoal suspension in $5 \% w / v$ suspension of acacia). Each subject was treated with a charcoal meal of $0.1 \mathrm{~mL} / 10 \mathrm{~g}$ (body weight) via the oral route. All mice were euthanized via cervical dislocation $30 \mathrm{~min}$ after administration of the charcoal meal. To measure intestinal transit, the stomach and small intestine were isolated. They were then extended to a clean surface. The distance moved by the charcoal meal from the pylorus and the total length of the small intestine were measured. Intestinal transit was expressed as a percentage of the distance traveled by charcoal over the total length from the pylorus to the cecum.

\subsection{Measurement of GE Rate with Phenol Red Marker}

GE was determined by the phenol red method. All studies were performed on mice after 2 weeks of treatment with DA-9701 or 3\% HPMC. After $16 \mathrm{~h}$ of fasting, the mice were treated orally with $1.5 \%$ carboxymethylcellulose (Sigma-Aldrich, Millipore, St. Louis, MI, USA) containing $0.05 \%$ phenol red (Sigma-Aldrich, Millipore, St. Louis, MI, USA) at a dose of $0.1 \mathrm{~mL} / 10 \mathrm{~g}, 1 \mathrm{~h}$ after treatment with 3\% HPMC or DA-9701. After another 
$30 \mathrm{~min}$, the mice were sacrificed by cervical dislocation. The abdomen was opened carefully and the gastroesophageal junction and pylorus were tied to prevent the contents from flowing out; the stomach was then separated. The extracted stomach was ground using a homogenizer in $0.1 \mathrm{M} \mathrm{NaOH}$, and the suspension was allowed to stabilize for $1 \mathrm{~h}$ at room temperature. Then, trichloroacetic acid ( $2 \%$ final concentration) was added and samples were centrifuged at $2500 \times g$ for $10 \mathrm{~min}$. The supernatant was mixed with $0.05 \mathrm{M} \mathrm{NaOH}$, and the amount of phenol red was measured colorimetrically at $560 \mathrm{~nm}$ using a microplate reader (Multiskan GO, Thermo Fisher Scientific, USA). The standard sample (zero-time control) was determined by the amount of phenol red recovered from mice sacrificed immediately after oral administration of $1.5 \%$ carboxymethylcellulose containing $0.05 \%$ phenol red. The gastric emptying rate was calculated using the following Equation:

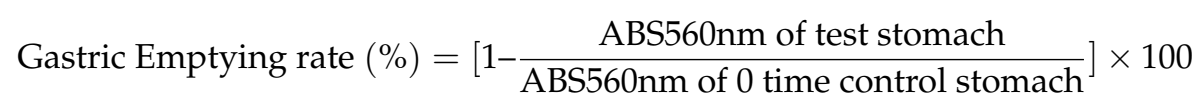

\subsection{Statistical Analysis}

Statistical analysis of the experimental results was performed with Student's t-test, using the Prism program (GraphPad Prism quickCalcs, San Diego, CA, USA). Statistical significance was set at $p<0.05$.

\section{Results}

\subsection{Blood Glucose and Body Weight in the STZ-Induced Diabetic Mice Model}

Two weeks after completion of the 3-day treatment with STZ or citric acid buffer, STZ-induced diabetic mice showed significantly higher blood glucose levels and lower body weight compared to normal controls $(p<0.05$, Figure 2$)$. There was no significant difference in the blood glucose concentration and the degree of body-weight loss in the diabetic group.

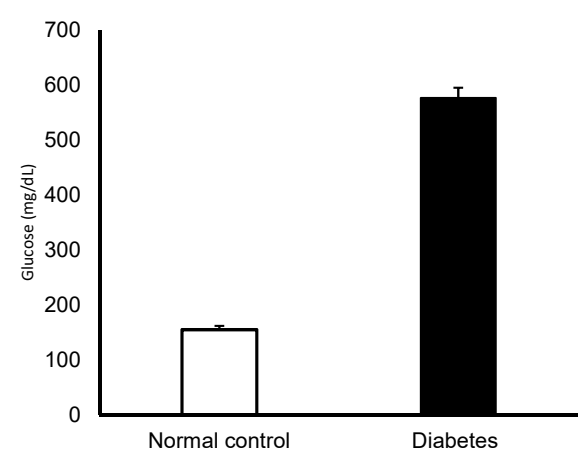

(A)

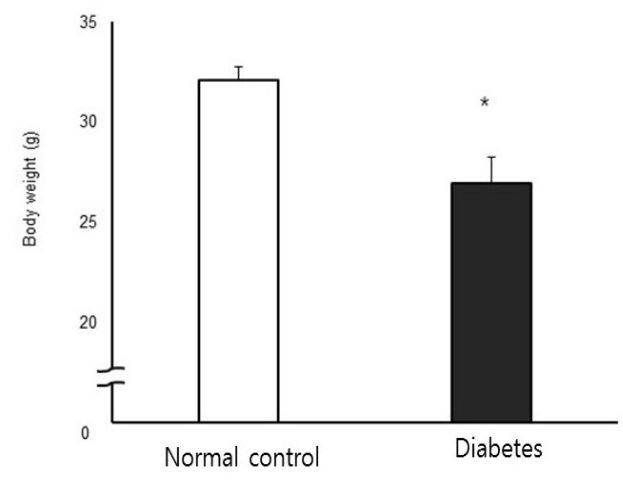

(B)

Figure 2. Blood glucose concentration (A) and body weight (B) in normal control and streptozotocininduced diabetic mice. STZ-induced diabetic mice showed significantly higher blood glucose levels and lower body weight compared to normal control ( $n=10$ in each group) ${ }^{*} p<0.05$. 
DA-9701 had no effect on either blood glucose level (Figure 3) or body weight (Figure 4) in STZ-induced diabetic mice.

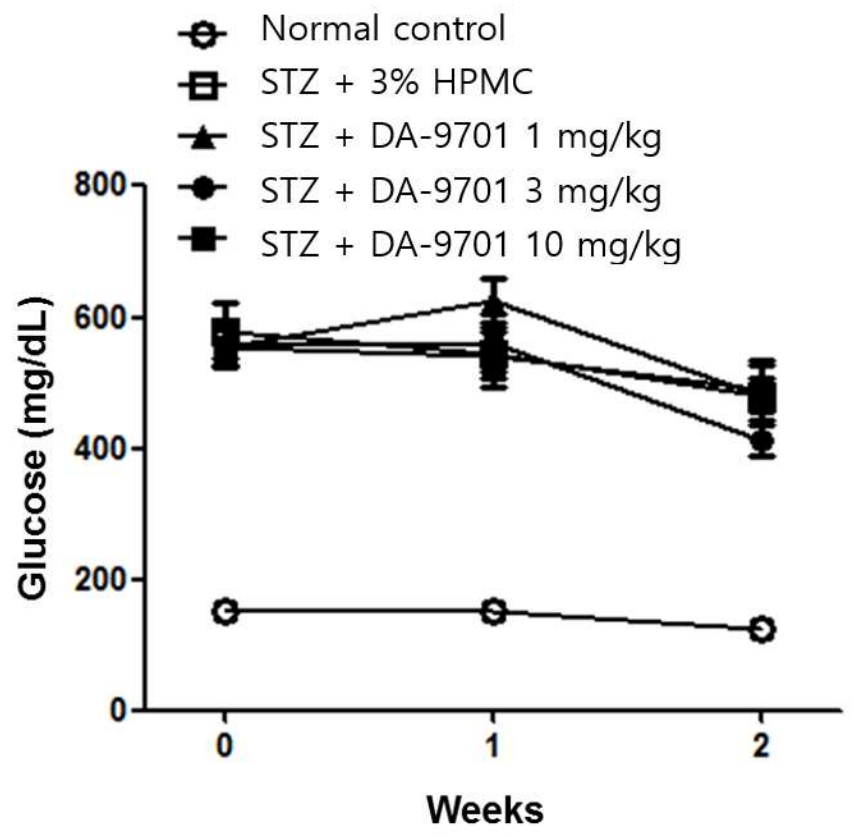

Figure 3. Effect of DA-9701 on blood glucose level in normal control and streptozotocin-induced diabetic mice. Streptozotocin-induced diabetic mice showed significantly higher blood glucose levels than control. DA-9701 did not affect blood glucose level in the streptozotocin-induced diabetic mice. ( $\mathrm{n}=10$ in each group).

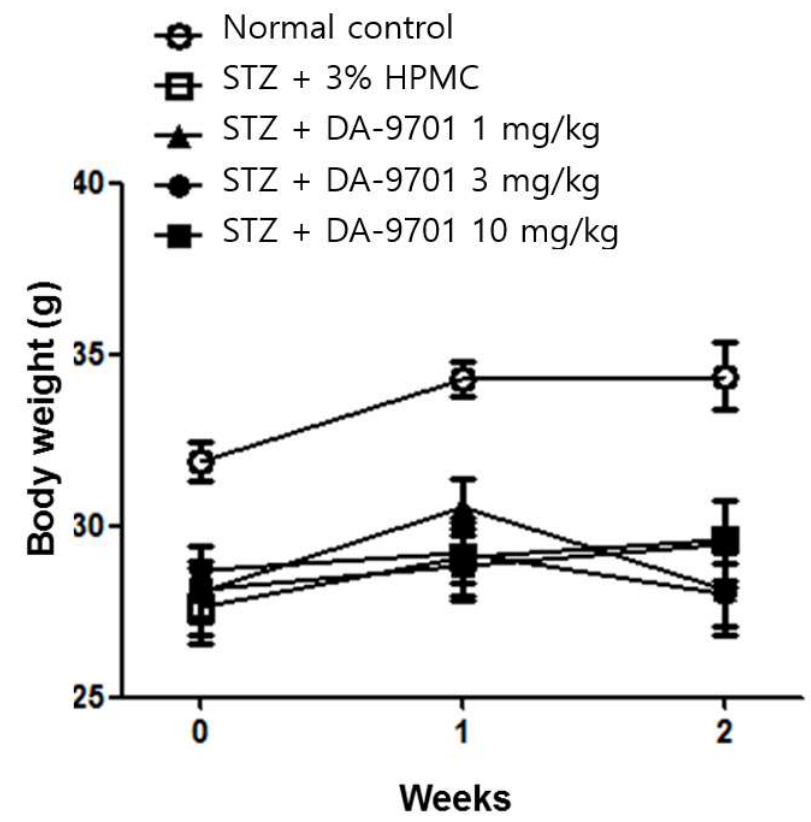

Figure 4. Effect of DA-9701 on body weight in normal control and streptozotocin-induced diabetic mice. STZ-induced diabetic mice had significantly lower body weight compared to control. DA-9701 had no effect on the body weight of the streptozotocin-induced diabetic mice. ( $\mathrm{n}=10$ in each group).

\subsection{GI Motility in the STZ-Induced Diabetic Mice Model}

The isometric contractions of the antrum and small bowel were significantly decreased in the STZ-induced diabetic mice group compared to the normal control group (100\% vs. $87.4 \%$, Figure $5 \mathrm{~A}$, and $100 \%$ vs. $87.4 \%$, Figure $5 \mathrm{~B}$ ). However, colonic motility was not significantly different between the groups (Figure 5C). 
A. Antral motiliy

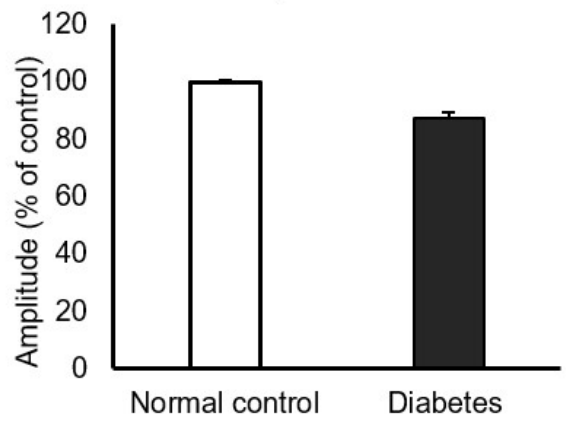

C. Colonic motility

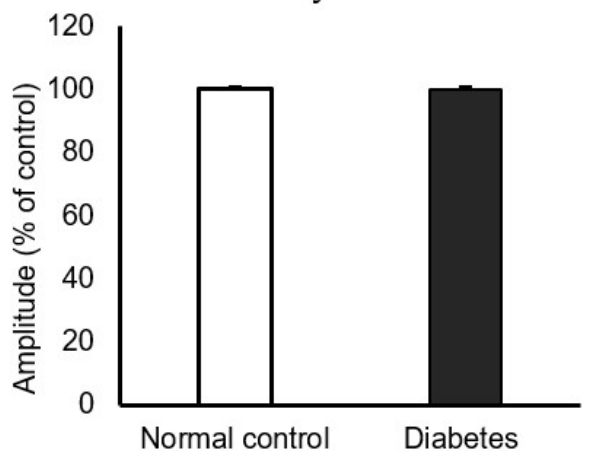

B. Small intestinal motility

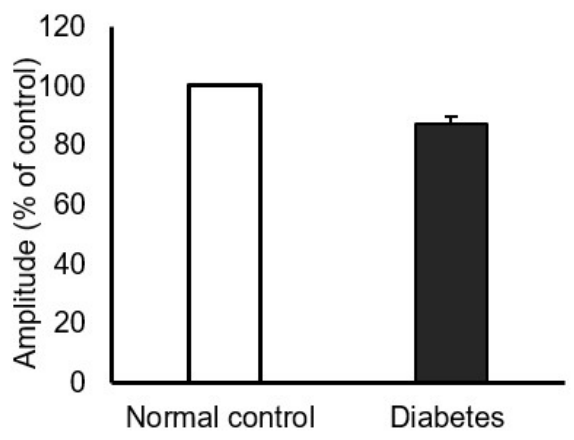

Figure 5. Antral, small intestinal, and colonic motility in normal control and streptozotocin-induced diabetic mice. The isometric contractions of each (A) antrum and (B) small bowel were significantly decreased in the streptozotocin-induced diabetic group compared to the normal control group ( $100 \%$ vs. $87.4 \%, 100 \%$ vs. $87.4 \%$ ). (C) Colonic motility was not different between the normal control and diabetic group (100\% vs. $100 \%)$. ( $\mathrm{n}=10$ in each group).

\subsection{Effects of DA-9701 on GI Motility}

The antral motility decreased in STZ-induced diabetic mice before any treatment and was increased after DA-9701 treatment in a dose-dependent manner (Figure 6). Although the antral motility in the diabetic group was improved according to the increased dosage of DA-9701, the amplitude was higher in the normal control group than in the diabetic group. However, the amplitude of antral motility was even higher in the diabetic group than in the normal control group at a dose of $>100 \mathrm{mg} / \mathrm{kg}$ of DA-9701.

In both the normal control and diabetic groups, DA-9701 increased spontaneous movement of the small intestinal muscle in a dose-dependent manner, without significant differences between the two groups. Motility showed no significant improvement in either diabetic or normal control groups under $30 \mathrm{mg} / \mathrm{kg}$ of DA-9701. However, the ileal muscular amplitude was significantly improved at over $30 \mathrm{mg} / \mathrm{kg}$ of DA-9701, with an increasing linear pattern $(p<0.05)$. This improvement was more prominent in the diabetic group (Figure 7).

Baseline colonic motility showed no definite difference between the diabetic and normal control groups. Despite the similar initial contractility between the two groups, colonic motility was dramatically improved after DA-9701 treatment in the diabetic group in a dose-dependent manner. In the control group, colonic motility did not respond to treatment with $30 \mathrm{mg} / \mathrm{kg}$ of DA-9701 and improved at over $30 \mathrm{mg} / \mathrm{kg}$ of DA-9701. However, the improvement was less than that in the diabetic group (Figure 8). 


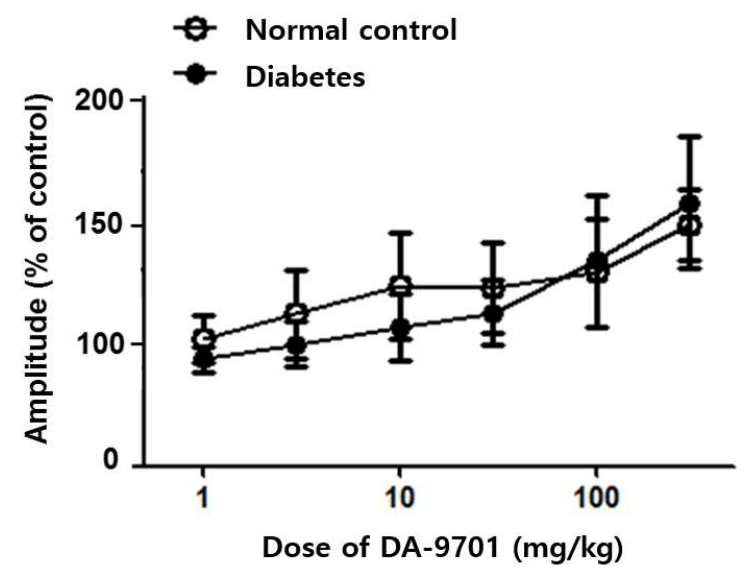

Figure 6. Effect of DA-9701 on antral motility in normal control and streptozotocin-induced diabetic mice. DA-9701 increased the spontaneous movement of the pyloric sinus ciliary muscle in a dosedependent manner in both normal control and diabetic groups, without significant difference between two groups. ( $\mathrm{n}=10$ in each group).

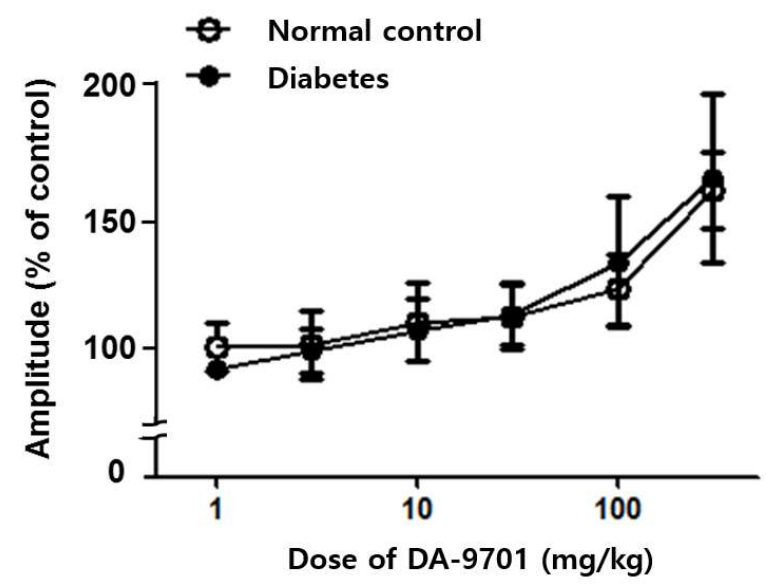

Figure 7. Effect of DA-9701 on small intestinal motility in normal control and streptozotocin-induced diabetic mice. In both the normal control and diabetic groups, DA-9701 increased the spontaneous movement of the small intestinal muscle in a dose-dependent manner, without significant difference between two groups. ( $\mathrm{n}=10$ in each group).

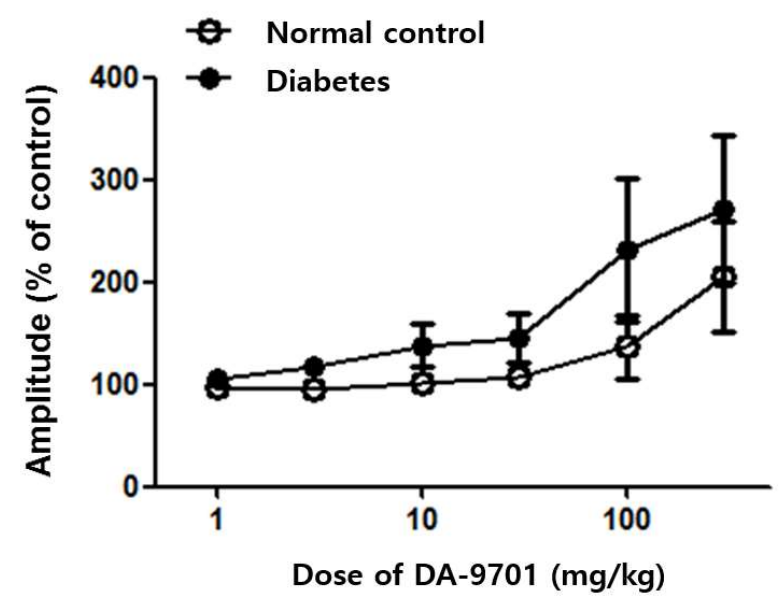

Figure 8. Effect of DA-9701 on colonic motility in normal control and streptozotocin-induced diabetic mice. DA-9701 administration showed a dose-dependent increase in the amplitude of spontaneous phasic contractions in the colon in normal controls and streptozotocin-induced diabetic mice, without significant difference between the two groups. ( $\mathrm{n}=10$ in each group). 


\subsection{Small Intestinal Transit and GE Rate in the STZ-Induced Diabetic Mice}

The intestinal transit decreased significantly in STZ-induced diabetic mice compared to normal controls ( $43 \pm 7 \%$ vs. $67 \pm 8 \%, p<0.05$, Figure 9 ).

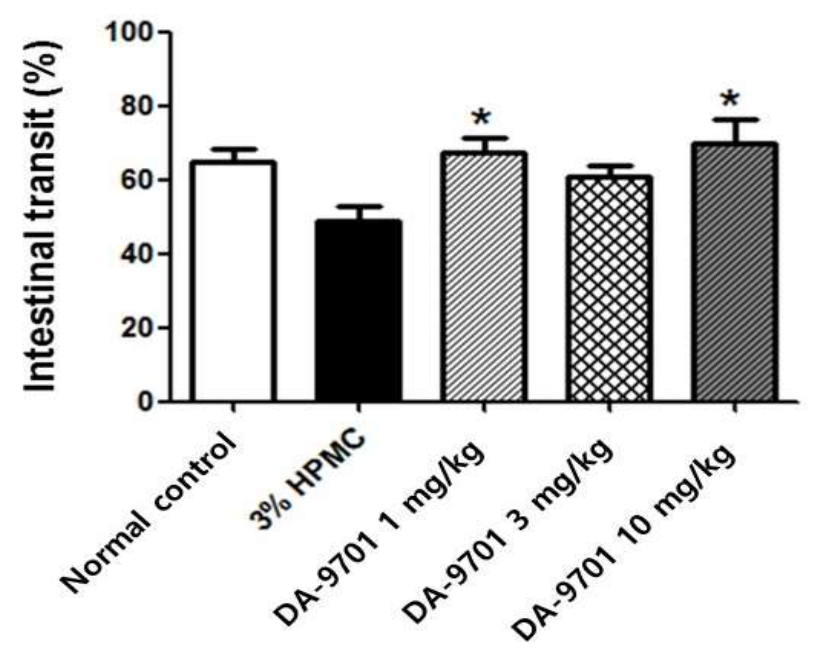

Figure 9. Effect of DA-9701 on intestinal transit in streptozotocin-induced diabetic mice. Intestinal transit was significantly decreased in streptozotocin-induced diabetic mice compared to normal control and improved in DA-9701 treatment group compared to placebo (3\% HPMC-treated) group. The intestinal transit was $67 \pm 4.0 \%, 60 \pm 4.2 \%, 70 \pm 6.6 \%$ in the treatment with $1 \mathrm{mg} / \mathrm{kg}, 3 \mathrm{mg} / \mathrm{kg}$, and $10 \mathrm{mg} / \mathrm{kg}$ of DA-9701, and $49 \pm 4.0 \%$ placebo groups, respectively. In particular, the intestinal transit improved significantly with $1 \mathrm{mg} / \mathrm{Kg}$ and $10 \mathrm{mg} / \mathrm{kg}$ of DA-9701 treatment compared to placebo $\left(\mathrm{n}=10\right.$ in each group ${ }^{*} p<0.05$.

The GE rate was also significantly delayed in the diabetic group compared to that in the normal control group ( $43 \pm 10 \%$ vs. $62 \pm 12 \%, p<0.05$, Figure 10$)$.

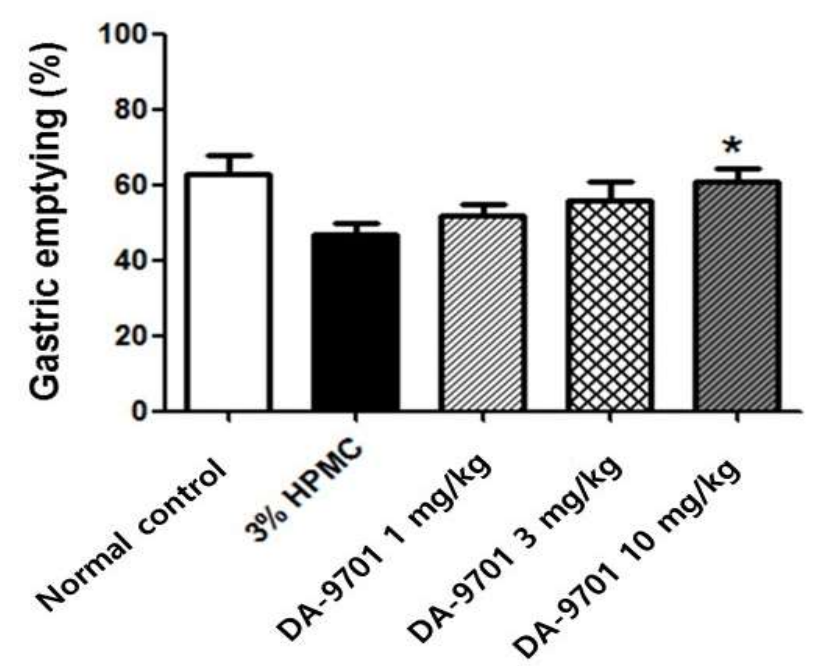

Figure 10. Effect of DA-9701 on gastric emptying in streptozotocin-induced diabetic mice. Gastric emptying was significantly delayed in streptozotocin-induced diabetic mice and improved with DA-9701 in a dose-dependent manner ( $50 \pm 11 \%, 55 \pm 12 \%$, and $60 \pm 11 \%$ in $1 \mathrm{mg} / \mathrm{kg}, 3 \mathrm{mg} / \mathrm{kg}$, and $10 \mathrm{mg} / \mathrm{kg}$ of DA-9701 treatment, respectively), compared to the $3 \%$ HPMC-treated placebo group. In particular, treatment with $10 \mathrm{mg} / \mathrm{kg}$ of DA-9701 significantly improved gastric emptying rate compared to placebo $\left(60 \pm 11 \%\right.$ vs. $\left.43 \pm 10 \%{ }^{*} p<0.05\right)(\mathrm{n}=10$ in each group).

\subsection{Effects of DA-9701 on Intestinal Transit}

Significantly decreased intestinal transit in STZ-induced diabetic mice was improved with DA-9701 treatment, compared to placebo ( $\%$ HPMC). The intestinal transit was 
$67 \pm 4.0 \%, 60 \pm 4.2 \%$, and $70 \pm 6.6 \%$ in the treatment with $1 \mathrm{mg} / \mathrm{kg}, 3 \mathrm{mg} / \mathrm{kg}$, and $10 \mathrm{mg} / \mathrm{kg}$ of DA- 9701 , and $49 \pm 4.0 \%$ placebo ( $3 \%$ HMC) groups, respectively. In particular, the intestinal transit improved significantly with $1 \mathrm{mg} / \mathrm{kg}$ and $10 \mathrm{mg} / \mathrm{kg}$ of DA-9701 treatment compared to placebo (Figure 9).

\subsection{Effects of DA-9701 on GE Rate}

Delayed GE in STZ-induced diabetic mice improved with administration of DA-9701 in a dose-dependent manner ( $50 \pm 11 \%, 55 \pm 12 \%$, and $60 \pm 11 \%$ at $1 \mathrm{mg} / \mathrm{kg}, 3 \mathrm{mg} / \mathrm{kg}$, and $10 \mathrm{mg} / \mathrm{kg}$ of DA-9701, respectively). In particular, treatment with $10 \mathrm{mg} / \mathrm{kg}$ of DA9701 significantly improved the GE rate compared to the placebo-treated diabetic group $(60 \pm 11 \%$ vs. $43 \pm 10 \%, p<0.05$, Figure 10$)$.

\section{Discussion}

Diabetic gastroparesis affects $20-50 \%$ of people with type 1 diabetes and $5 \%$ of patients who have been diagnosed with type 2 diabetes for more than 10 years [8]. The stomach is more susceptible to diabetic complications than the small intestine; approximately $75 \%$ of patients with diabetes have gastrointestinal symptoms, one-third of whom have stomach symptoms $[9,10]$.

It is considered that this disease spectrum can be caused by autonomic neuropathy $[3,11]$. Diabetes causes loss of myelinated sympathetic trunk fibers and enlarged dystrophic axons and nerve terminals in the prevertebral sympathetic ganglia [12]. ICC loss in diabetes has been observed in human and animal models [13,14]. Reduced insulin and IGF-1 signaling may cause ICC loss, smooth muscle atrophy, and reduced stem cell factor production [15]. Another mechanism is that oxidative stress results in the loss of heme oxygenase 1 (HO1)-containing macrophages. $\mathrm{HO} 1$ is an enzyme expressed in macrophages and has a protective effect against oxidative stress. The main source of HO1 is the stomach muscle wall [10]. Pathological findings associated with gastric sensorimotor dysfunction can occur; these include delayed GE, gastric dysrhythmia, fundic accommodation, weakened antral pump, antroduodenal discoordination, duodenal neuromuscular dysfunction, and abnormal duodenal feedback [16,17].

This study presented several important findings associated with diabetic gastroparesis and gastroenteropathy. First, GI motility significantly decreased with site selectivity in diabetic conditions. The bowel motility power was found to be weak from the stomach to the small intestine in a diabetic model; however, colonic motility showed no significant decline. Although various factors may affect the colonic symptoms, this finding is one explanation for why diabetic patients present with various colonic symptoms, such as diarrhea, abdominal pain, and constipation. Second, GI transit and GE were appreciably delayed in STZ-induced diabetic mice compared to normal controls. Finally, DA-9701, which has been developed as a prokinetic drug, restored the decreased GI motility and delayed intestinal transit and GE in STZ-induced diabetic mice.

The present study confirmed that gastric and small intestinal motility decreased in STZ-induced diabetic mice compared to that in normal mice. However, colonic motility was not significantly decreased in STZ-induced diabetic mice. There is a lack of well-designed studies on abnormal colonic motility in patients with diabetes [18]. However, there is a pathological change in large bowel motility because lower GI symptoms, such as diarrhea or constipation, are easily noted in longstanding diabetic patients. There is some evidence of delayed colonic transit, colonic myenteric neuronal loss, [19] anorectal dysfunction due to impaired external anal sphincter function, diminished rectal sensation to distension [18], and increased oxidative stress in colonic tissues [19]. Although muscular strength in the colon was preserved in our model, there could be other structural abnormalities or early changes in another colonic site. The definite mechanism in diabetic gastroparesis should be revealed in future studies using multiple samples from the GI tract.

This study showed that DA-9701 was effective in improving GI motility, small bowel transit, and gastric emptying in STZ-induced diabetic mice. Interestingly, the changes in 
motility amplitude were greater in the colon than in the antral or small intestine after DA9701 treatment. Although the baseline colonic motility in STZ-induced diabetic mice was not different from that in control mice, the response to the drug was more remarkable in the colon than in other organs. DA-9701 improved functional constipation in non-diabetic patients by accelerating colonic transit in a single-center experience [20]. However, this drug did not improve constipation symptoms in patients with Parkinson's disease [21]. Further studies are required to determine whether DA-9701 would improve lower GI symptoms more than upper GI symptoms in diabetic patients, and furthermore, how DA-9701 increases colonic motility more than other organs in a diabetic model.

In this study, DA-9701 improved both small intestinal transit and GE in a dosedependent manner. Many investigators have reported the effect of DA-9701 on the restoration of reduced GI transit and GE. Ramsbottom et al. [22] compared the efficacy of DA-9701 in GE with cisapride, clonidine, and apomorphine in a delayed GE model. The prokinetic effects of DA-9701 were comparable to those of cisapride $(10 \mathrm{mg} / \mathrm{kg})$ in normal animals and a delayed GE model at doses of $0.3-3 \mathrm{mg} / \mathrm{kg}$ [6]. In an in vitro study using an ICC, it was suggested that DA-9701 might affect GI motility by modulating pacemaker activity in the ICC $[23,24]$. DA-9701 accelerated GE, which was confirmed by a 13C-octanoic acid breath test with repeated measurements in normal mice [25]. DA-9701 improved stress-induced delayed GE, and this effect might be associated with the inhibition of stress-induced increases in plasma levels of adrenocorticotropic hormone (ACTH) and ghrelin [26]. The first multicenter, double-blind, randomized clinical trial was performed with concealed allocation, comparing the safety and efficacy of DA-9701 and itopride hydrochloride in Korea [24]. DA-9701 significantly improved both functional dyspepsia symptoms and quality of life in patients with functional dyspepsia. The efficacy of DA-9701 was not inferior to that of itopride [24]. Although DA-9701 was effective in treating functional gastric diseases, the effects of this drug in diabetic patients have not been proven yet. Thus, our results provide evidence for the use of DA-9701 in the treatment of diabetic gastroparesis and gastroenteropathy. Because of the heterogeneous symptom pattern and various causes of functional gastroparesis in diabetic patients, effective and safe doses of DA-9701 according to symptoms should be confirmed in a future study.

This study has several limitations. First, colonic motility was not significantly decreased in patients with diabetes. This might be explained by insufficient diabetic stimulation of the colon or the short duration of diabetes. Dysregulated colonic motility occurs in the advanced diabetic stage. Second, a colonic transit study of diabetes patients was not included in this study. To demonstrate the mechanism of colonic motility improvement, colonic transit or neuronal studies in colonic tissue should be performed. Further studies on the pathological findings and colonic motility function using DA-9701 will be required in diabetic animal models and clinical settings. Finally, the clinical application of DA-9701 should be added to prove its positive effect on diabetic gastroparesis. Although DA-9701 was proven to be effective in functional gastroparesis, diabetic gastroparesis is different from general functional disorders.

\section{Conclusions}

In conclusion, DA-9701 improved GI contractility without affecting blood sugar and body weight in STZ-induced diabetic mice, similar to the normal controls; in particular, it had a good effect on increasing colon motility in normal and diabetic mice. The efficacy of DA-9701 in intestinal transit and gastric emptying was similar in STZ-induced diabetic mice and normal mice. DA-9701 might be helpful in improving decreased upper and lower GI motility and various clinical symptoms in patients with progressive diabetes. Further studies are required to evaluate the effect of DA-9701 on various bowel motility dysfunctions, even in advanced diabetic patients. 
Author Contributions: C.H. experimented, analyzed and interpreted the data, and wrote the manuscript; O.-J.L. and H.K. (Heejin Kim) designed, organized and supervised the manuscript; H.K. (Hyunjin Kim), R.C., J.L., S.L. and J.-H.R. supported the statistical analysis and helped to prepare manuscript including tables and the figures, and mediated the present study. All authors have read and agreed to the published version of the manuscript.

Funding: This research received no external funding.

Institutional Review Board Statement: All animal care and experimental procedures were approved by the Ethics of Animal Experiments Committee of Gyeongsang National University (GNU-210928-M0081).

Informed Consent Statement: Informed consent was obtained from all subjects involved in the study.

Data Availability Statement: The data presented in this study are available on request from the corresponding author.

Conflicts of Interest: The authors declare no conflict of interest.

\section{References}

1. Parkman, H.P.; Hasler, W.L.; Fisher, R.S. American Gastroenterological Association technical review on the diagnosis and treatment of gastroparesis. Gastroenterology 2004, 127, 1592-1622. [CrossRef]

2. Krishnasamy, S.; Abell, T.L. Diabetic Gastroparesis: Principles and Current Trends in Management. Diabetes Ther. Res. Treat. Educ. Diabetes Relat. Disord. 2018, 9, 1-42. [CrossRef]

3. Yagihashi, S.; Sima, A.A. Diabetic autonomic neuropathy in BB rat. Ultrastructural and morphometric changes in parasympathetic nerves. Diabetes 1986, 35, 733-743. [CrossRef]

4. Kwon, Y.S.; Son, M. DA-9701: A New Multi-Acting Drug for the Treatment of Functional Dyspepsia. Biomol. Ther. 2013, 21, 181-189. [CrossRef]

5. Kim, E.R.; Min, B.H.; Lee, S.O.; Lee, T.H.; Son, M.; Rhee, P.L. Effects of DA-9701, a novel prokinetic agent, on gastric accommodation in conscious dogs. J. Gastroenterol. Hepatol. 2012, 27, 766-772. [CrossRef]

6. Lee, T.H.; Choi, J.J.; Kim, D.H.; Choi, S.; Lee, K.R.; Son, M.; Jin, M. Gastroprokinetic effects of DA-9701, a new prokinetic agent formulated with Pharbitis Semen and Corydalis Tuber. Phytomed. Int. J. Phytother. Phytopharm. 2008, 15, 836-843. [CrossRef]

7. Lee, S.P.; Lee, K.N.; Lee, O.Y.; Lee, H.L.; Jun, D.W.; Yoon, B.C.; Choi, H.S.; Hwang, S.J.; Lee, S.E. Effects of DA-9701, a novel prokinetic agent, on phosphorylated extracellular signal-regulated kinase expression in the dorsal root ganglion and spinal cord induced by colorectal distension in rats. Gut Liver 2014, 8, 140-147. [CrossRef] [PubMed]

8. Sanders, K.M.; Ordog, T.; Koh, S.D.; Ward, S.M. A Novel Pacemaker Mechanism Drives Gastrointestinal Rhythmicity. News Physiol. Sci. Int. J. Physiol. Prod. Jt. By Int. Union Physiol. Sci. Am. Physiol. Soc. 2000, 15, 291-298. [CrossRef]

9. Waseem, S.; Moshiree, B.; Draganov, P.V. Gastroparesis: Current diagnostic challenges and management considerations. World J. Gastroenterol. 2009, 15, 25-37. [CrossRef]

10. Choi, K.M.; Gibbons, S.J.; Nguyen, T.V.; Stoltz, G.J.; Lurken, M.S.; Ordog, T.; Szurszewski, J.H.; Farrugia, G. Heme Oxygenase1 Protects Interstitial Cells of Cajal From Oxidative Stress and Reverses Diabetic Gastroparesis. Gastroenterology 2008, 135, 2055-2064.e2. [CrossRef]

11. Kniel, P.C.; Junker, U.; Perrin, I.V.; Bestetti, G.E.; Rossi, G.L. Varied effects of experimental diabetes on the autonomic nervous system of the rat. Lab. Investig. A J. Tech. Methods Pathol. 1986, 54, 523-530.

12. Duchen, L.W.; Anjorin, A.; Watkins, P.J.; Mackay, J.D. Pathology of autonomic neuropathy in diabetes mellitus. Ann. Intern. Med. 1980, 92, 301-303. [CrossRef]

13. Iwasaki, H.; Kajimura, M.; Osawa, S.; Kanaoka, S.; Furuta, T.; Ikuma, M.; Hishida, A. A deficiency of gastric interstitial cells of Cajal accompanied by decreased expression of neuronal nitric oxide synthase and substance P in patients with type 2 diabetes mellitus. J. Gastroenterol. 2006, 41, 1076-1087. [CrossRef] [PubMed]

14. Lin, Z.; Sarosiek, I.; Forster, J.; Damjanov, I.; Hou, Q.; McCallum, R.W. Association of the status of interstitial cells of Cajal and electrogastrogram parameters, gastric emptying and symptoms in patients with gastroparesis. Neurogastroenterol. Motil. 2010, 22, 56-61.e10. [PubMed]

15. Horváth, V.J.; Vittal, H.; Lörincz, A.; Chen, H.; Almeida-Porada, G.; Redelman, D.; Ördög, T. Reduced Stem Cell Factor Links Smooth Myopathy and Loss of Interstitial Cells of Cajal in Murine Diabetic Gastroparesis. Gastroenterology 2006, 130, 759-770. [CrossRef]

16. Kindt, S.; Dubois, D.; Van Oudenhove, L.; Caenepeel, P.; Arts, J.; Bisschops, R.; Tack, J. Relationship between symptom pattern, assessed by the PAGI-SYM questionnaire, and gastric sensorimotor dysfunction in functional dyspepsia. Neurogastroenterol. Motil. 2009, 21, 1183-e1105. [CrossRef]

17. Kim, B.J.; Kuo, B. Gastroparesis and Functional Dyspepsia: A Blurring Distinction of Pathophysiology and Treatment. J. Neurogastroenterol. Motil. 2019, 25, 27-35. [CrossRef] [PubMed]

18. Phillips, L.K.; Rayner, C.K.; Jones, K.L.; Horowitz, M. An update on autonomic neuropathy affecting the gastrointestinal tract. Curr. Diabetes Rep. 2006, 6, 417-423. [CrossRef] [PubMed] 
19. Chandrasekharan, B.; Anitha, M.; Blatt, R.; Shahnavaz, N.; Kooby, D.; Staley, C.; Mwangi, S.; Jones, D.P.; Sitaraman, S.V.; Srinivasan, S. Colonic motor dysfunction in human diabetes is associated with enteric neuronal loss and increased oxidative stress. Neurogastroenterol. Motil. 2011, 23, 131-138. [CrossRef]

20. Kim, S.Y.; Woo, H.S.; Kim, K.O.; Choi, S.H.; Kwon, K.A.; Chung, J.; Kim, Y.J.; Kim, J.H.; Park, D.K. DA-9701 improves colonic transit time and symptoms in patients with functional constipation: A prospective study. J. Gastroenterol. Hepatol. 2017, 32, 1943-1948. [CrossRef] [PubMed]

21. Choi, J.H.; Lee, J.Y.; Cho, J.W.; Koh, S.B.; Yang, Y.S.; Yoo, D.; Shin, C.M.; Kim, H.T. Double-Blind, Randomized, Placebo-Controlled Trial of DA-9701 in Parkinson's Disease: PASS-GI Study. Mov. Disord. Off. J. Mov. Disord. Soc. 2020, 35, 1966-1976. [CrossRef] [PubMed]

22. Ramsbottom, N.; Hunt, J.N. Studies of the effect of metoclopramide and apomorphine on gastric emptying and secretion in man. Gut 1970, 11, 989-993. [CrossRef]

23. Choi, S.; Choi, J.J.; Jun, J.Y.; Koh, J.W.; Kim, S.H.; Kim, D.H.; Pyo, M.Y.; Choi, S.; Son, J.P.; Lee, I.; et al. Induction of pacemaker currents by DA-9701, a prokinetic agent, in interstitial cells of Cajal from murine small intestine. Mol. Cells 2009, 27, 307-312. [CrossRef]

24. Choi, M.-G.; Rhee, P.-L.; Park, H.; Lee, O.Y.; Lee, K.J.; Choi, S.C.; Seol, S.Y.; Chun, H.J.; Rew, J.-S.; Lee, N.H.; et al. Randomized, Controlled, Multi-center Trial: Comparing the Safety and Efficacy of DA-9701 and Itopride Hydrochloride in Patients With Functional Dyspepsia. J. Neurogastroenterol. Motil. 2015, 21, 414-422. [CrossRef] [PubMed]

25. Lim, C.-H.; Choi, M.-G.; Park, H.; Baeg, M.K.; Park, J.M. Effect of DA-9701 on gastric emptying in a mouse model: Assessment by 13C-octanoic acid breath test. World J. Gastroenterol. 2013, 19, 4380-4385. [CrossRef]

26. Jung, Y.S.; Kim, M.Y.; Lee, H.S.; Park, S.L.; Lee, K.J. Effect of DA-9701, a novel prokinetic agent, on stress-induced delayed gastric emptying and hormonal changes in rats. Neurogastroenterol. Motil. 2013, 25, 254-259.e166. [CrossRef] [PubMed] 